\title{
The multi-factor recombination and processes superimposition model for hydrocarbon accumulation: application to the Silurian in the Tarim Basin
}

\author{
Meng Qingyang ${ }^{1,2}$, Pang Xiongqi ${ }^{1,2 *}$ and Gao Jianbo ${ }^{3}$ \\ ' State Key Laboratory of Petroleum Resource and Prospecting, China University of Petroleum Beijing 102249, China \\ ${ }^{2}$ Basin and Reservoir Research Center, China University of Petroleum Beijing 102249, China \\ ${ }^{3}$ Research Center, CNOOC, Beijing 100027, China
}

\begin{abstract}
The multi-factor recombination and processes superimposition model for hydrocarbon accumulation is put forward in view of the hydrocarbon geological characteristics of multiple episodes of structural evolution, multiple sets of source-reservoir-seal assemblage, multiple cycles of hydrocarbon accumulation and multiple episodes of readjustment and reconstruction in the complex superimposed basins in China. It is a system including theories and methods that can help to predict favorable exploration regions. According to this model, the basic discipline for hydrocarbon generation, evolution and distribution in the superimposed basins can be summarized in multi-factor recombination, processes superimposition, multiple stages of oil filling and latest stage preservation. With the Silurian of the Tarim basin as an example, based on the reconstruction of the evolution history of the four factors (paleo-anticline, source rock, regional cap rock and kinematic equilibrium belt) controlling hydrocarbon accumulation, this model was adopted to predict favorable hydrocarbon accumulation areas and favorable exploration regions following structural destruction in three stages of oil filling, to provide guidance for further exploration of oil and gas in the Silurian of the Tarim basin.
\end{abstract}

Key words: Multi-factor recombination, processes superimposition, Tarim Basin, Silurian, favorable exploration region prediction

\section{The multi-factor recombination and processes superimposition" model for hydrocarbon accumulation}

Based on the understanding of the hydrocarbon geological characteristics and main controlling factors on hydrocarbon accumulation in the complex superimposed basins in China, a new hydrocarbon accumulation model, "multi-factor recombination and processes superimposition model", is put forward, which is a system of theories and methods to predict the favorable exploration regions in the superimposed basins in China (Pang et al, 2007). The main contents of this model can be summarized in four aspects, including "multi-factor recombination, processes superimposition, multiple stages of oil filling and latest stage preservation"(Table 1).

\subsection{Multi-factor recombination}

The Tarim basin is a typical superimposed basin in west China. Previous studies by numerous researchers (He et al, 2005; Jin and Wang, 2004; Jin, 2005; Pang et al, 2002; Zhou, 1997; 2000; Zhou et al, 2004; Zhao et al, 2003; Zhang et al, 2002;Jiang et al, 2006; Chen et al, 2006 ) show that

*Corresponding author. email: pangxq@cup.edu.cn Received March 19, 2007 the main factors controlling hydrocarbon accumulation are the source rock kitchen, paleo-anticline, regional cap rock and kinematic equilibrium belt (Pang et al, 2006; 2008). Kinematic equilibrium belt is defined as a belt that is affected the least by tectonic movement during multiple elevation and subsidence movement. It is usually located in the transitional area of different subsidence centers in different period and has essential difference with transfer zone between two different tectonic system. The kinematic equilibrium belt can be defined according to the erosion thickness in some area. The best favorable kinematic equilibrium belt is where the erosion thickness is $100 \mathrm{~m}-200 \mathrm{~m}$. And favorable kinematic equilibrium belt is where the erosion thickness is between $0-100 \mathrm{~m}$ and $200-300 \mathrm{~m}$. When the erosion thickness is more than $300 \mathrm{~m}$, it is not kinematic equilibrium belt. For a given oil filling stage, the favorable area for hydrocarbon accumulation is the place where the four controlling factors are overlapped in a plan view. If any one factor is absent, the place will not be favorable for hydrocarbon accumulation.

\subsection{Processes superimposition}

The hydrocarbon accumulation formed in the early stage will be affected by subsequent tectonic disturbances. If the favorable accumulation area formed in the early stage is within the kinematic equilibrium belt of the later stage, then 
Table 1 The model of "multi-factors recombination and processes superimposition" in superimposed basins and its predicting and prospecting model

\begin{tabular}{|c|c|c|c|c|c|}
\hline \multicolumn{2}{|c|}{ Key point } & Basic concept & Geological model & \multirow[b]{2}{*}{\begin{tabular}{|c|} 
Application method \\
favorable accumulation area prediction \\
A type (four factor combination) \\
B type (three factor combination) \\
C type (two factor combination) \\
D type (one factor combination) \\
\end{tabular}} & \multirow[b]{2}{*}{\begin{tabular}{|l} 
Comment \\
\\
\end{tabular}} \\
\hline I & 竎 & $\begin{array}{l}\text { The area combined by } \\
\text { paleohigh, source rock } \\
\text { kichen, regional cap rock } \\
\text { and equilibrium belt is the } \\
\text { favorable hydrocarbon } \\
\text { accumulation area. }\end{array}$ & $\begin{array}{l}1 \text { paleohigh control } \\
\text { hydrocarbon } \\
2 \text { source rock } \\
\text { kitchen control } \\
\text { hydrocarbon } \\
3 \text { regional cap rock } \\
\text { control hydrocarbon } \\
4 \text { equilibrium belt } \\
\text { control hydrocabon }\end{array}$ & & \\
\hline II & 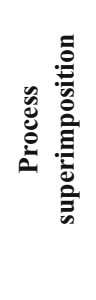 & $\begin{array}{l}\text { The superimposed area } \\
\text { of equilibrium belt after } \\
\text { accumulation period is } \\
\text { favorable to hydrocarbon } \\
\text { enrichment and maintain. }\end{array}$ & $\begin{array}{l}1 \text { one period } \\
\text { equilibrium belt } \\
2 \text { two period } \\
\text { equilibrium belt } \\
3 \text { three period } \\
\text { equilibrium belt }\end{array}$ & \begin{tabular}{|c} 
favorable exploration area prediction \\
A type (continuous equilibrium belt \\
superimposition) \\
B type (several equilibrium belt \\
superimposition) \\
C type \\
$\begin{array}{c}\text { (few equilibrium belt } \\
\text { superimposition) }\end{array}$ \\
$\begin{array}{c}\text { (no equilibrium belt } \\
\text { D typerimposition) }\end{array}$
\end{tabular} & ฟ \\
\hline III & 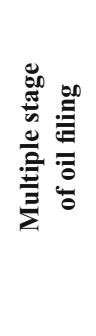 & $\begin{array}{l}\text { The same target formation } \\
\text { in the same area can be } \\
\text { charged petroliferous fluid } \\
\text { in different source rock } \\
\text { and different period. }\end{array}$ & $\begin{array}{l}1 \text { one period } \\
\text { accumulation } \\
2 \text { two period } \\
\text { accumulation } \\
3 \text { three period } \\
\text { accumulation }\end{array}$ & $\begin{array}{c}\text { Mixed source rock hydrocarbon } \\
\text { distribution prediction } \\
\text { A type (multi-source,multi-period and } \\
\text { multi-formation) } \\
\text { B type (multi-source,multi-period and } \\
\text { one formation) } \\
\text { C type (multi-source,one-period and } \\
\text { one formation) } \\
\begin{array}{c}\text { D type (one-source,one-period and } \\
\text { one formation) }\end{array}\end{array}$ & 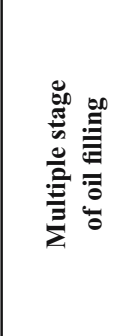 \\
\hline IV & 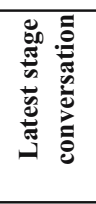 & $\begin{array}{c}\text { The latest hydrocaron } \\
\text { accumulation and tectonic } \\
\text { change has more effects } \\
\text { than the early period to } \\
\text { exploration potential. }\end{array}$ & $\begin{array}{c}\mathrm{PPI}=\left(\sum \mathrm{RF}_{\mathrm{i}} \cdot \mathrm{K}_{\mathrm{i}}+\sum \mathrm{R} D_{\mathrm{j}} \cdot \mathrm{K}_{\mathrm{j}}\right) / \mathrm{PPIM} \\
\mathrm{PPI} / \mathrm{PPIM}-\text { potential index } \text { theoretical maximum; } \\
\mathrm{RF}_{\mathrm{i}}, \mathrm{K}_{\mathrm{i}}-\text { the } \mathrm{i} \text { time accumulation index/weight index; } \\
\mathrm{RD}_{\mathrm{j}}, \mathrm{K}_{\mathrm{j}}-\text { the } \mathrm{j} \text { time adjustment index/weight index. }\end{array}$ & $\begin{array}{l}\text { Exploration potential index } \\
\text { A type }(\mathrm{PPI}>0.75) \\
\text { B type }(\mathrm{PPI}=0.75-0.50) \\
\mathrm{C} \text { type }(\mathrm{PPI}=0.50-0.25) \\
\text { D type }(\mathrm{PPI}<0.25)\end{array}$ & 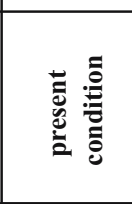 \\
\hline
\end{tabular}

the hydrocarbon accumulations will not be destroyed and can even be enlarged in size. If not, the hydrocarbon accumulation formed in early stage will be adjusted, reconstructed or even destroyed. According to the superimposition condition of the kinematic equilibrium belt following one stage of oil filling, we classify the favorable areas into four categories: the most favorable area (all within the kinematic equilibrium belt), favorable area (most stages within the kinematic equilibrium belt), relatively favorable area (some stages within the kinematic equilibrium belt) and unfavorable area (never within the kinematic equilibrium belt).

\subsection{Multiple stages of oil filling}

For a particular exploration interval, the hydrocarbon accumulation should be the results of multiple stages of oil filling in the geological past. On the basis of multi-factor combination and processes superimposition, favorable hydrocarbon accumulation areas after adjustment and reconstruction of later stages can be recognized. Then by combining the favorable hydrocarbon accumulation areas in each different stage, the most favorable area, relatively favorable area and less favorable area for hydrocarbon accumulation in one exploration interval can be recognized. At the same time, the oil filling stages can also be recognized for the different categories of favorable areas.

\subsection{Latest stage preservation}

Following multi-cycles of hydrocarbon accumulation and multiple stages of tectonic disturbance, the presently discovered hydrocarbon accumulations are mostly shaped in the latest stage of oil filling. Their distribution is the combination and coupling of the most favorable exploration region in different stages of oil filling after later adjustment, reconstruction and destruction. For example, in the same trap of the Silurian in the Tazhong uplift of the Tarim basin, both dry bitumen from the early stage of oil filling and light oil from the later stage of oil filling can be found, which is the result of hydrocarbons derived from different stages of oil filling and contained in the same trap. Since the latest stage of tectonic disturbance and hydrocarbon accumulating is critical to the exploration potential, the favorable exploration region in the latest oil filling stage should be highly valued when being superimposed with that of other stages.

\section{Timing of oil filling in the Silurian of the Tarim basin}

Numerous scholars ( Jin et al, 2006; Zhang and Huang, 2005; Lu et al, 1999; 2005; 2007; Lu and Hu, 1998; Liu et al, 2007) have studied the oil filling stages in the Silurian of the Tarim basin. Although they have adopted different approaches 
to identify the oil filling stages and the results are not the same, in general, the concept of three stages of oil filling is accepted by most of the scholars. After the recovery of hydrocarbon expulsion history by Cambrian and Ordovician source rocks, we classify the charging history into three oil filling stages for the Silurian of the Tarim basin (Table 2).

\section{Restoration of all factors controlling hydrocarbon accumulation in the Silurian}

On the basis of studies of the tectonic evolution history, we restored the geological characteristics of the four factors controlling hydrocarbon accumulation in the Silurian during three oil filling stages. They include the distribution and development of paleo-anticline, the shift of source rock kitchen and hydrocarbon generation and expulsion intensity features, the distribution of regional cap rock and distribution of kinematic equilibrium belt during the main tectonic disturbances. The restoration form the basis for predicting the favorable hydrocarbon accumulation area. Fig. 1 is the restoration result of key controlling factors during the first oil filling stage of the Silurian.

\section{Prediction of favorable Silurian exploration regions in the Tarim basin}

\subsection{Prediction of favorable Silurian exploration regions by following factors combination principle}

According to the factors combination principle, the favorable Silurian exploration regions during the first oil filling stage are predicted. Fig. 2 is the combination results of four key controlling factors including paleo-anticline, source rock kitchen, regional cap rock, and kinematic equilibrium belt. The figure shows that the most favorable exploration fairway is located in most of the areas surrounding the Manjiaer Sag, Yingmaili low uplift of the northern Awati Sag, Wensu uplift and its south edge near the Bachu Arch.

\subsection{Prediction of favorable Silurian exploration regions by following the processes superimposition principle}

According to the processes superimposition principle, the favorable Silurian exploration region during the first oil filling stage would be adjusted and reconstructed by tectonic disturbance of the second and third oil filling stages. Thus, the real favorable area should eliminate the part adjusted and reconstructed by subsequent tectonic disturbances of later oil filling stages. Fig. 3 is the prediction result of the favorable area adjusted and reconstructed. It can be seen from the figure that the adjustment and reconstruction of later oil filling stages did not affect the favorable area of early oil filling stage, so that the favorable area with four key controlling factors combination in the first oil filling stage is the most favorable exploration region.

\subsection{Prediction of favorable Silurian exploration regions by following the multiple oil filling stage principle}

The Silurian reservoirs were characterized by three stages of oil filling. Firstly the favorable hydrocarbon accumulation area during the three oil filling stages after adjustment and reconstruction by tectonic disturbance should be separately predicted. Then the most favorable Silurian exploration region in the three oil filling stages can be predicted by combining the favorable area of three oil filling stages in the plane. Fig. 4 is the prediction result for the favorable area of the second and third oil filling stage after later adjustment and reconstruction by tectonic disturbance.

\subsection{Prediction of favorable Silurian exploration regions by following the latest stage preservation principle}

On the basis of the above prediction of the favorable exploration regions, the most favorable Silurian exploration regions were predicted by combining the favorable area of three oil filling stages with different weighting proportions in the plain according to the latest stage preservation principle. It can be seen from Fig. 5 that the most favorable exploration region for all the three oil filling stages lies in the southeast edge of the Manjiaer Sag near the Kongquehe slope, and the favorable exploration region for two oil filling stages lies in the eastern part of the Tazhong low uplift, the northwest part of the Awati Sag, the west part of the Luntai uplift, the northwest part of the Kongquehe slope and the Yingjisu depression.

\section{Conclusion and discussion}

\subsection{Conclusion}

The model of "multi-factors recombination and processes superimposition" is adopted in this paper to separately predict

Table 2 Classification on the stage of Silurian hydrocarbon accumulation by different scholars

\begin{tabular}{|c|c|c|c|c|c|c|}
\hline Stage Scholar & $\begin{array}{c}\text { Song and Wu } \\
\text { (2004) }\end{array}$ & $\begin{array}{l}\text { Li et al } \\
(2002)\end{array}$ & $\begin{array}{c}\text { Chen and Jiang } \\
(2005)\end{array}$ & $\begin{array}{l}\text { Liu et al } \\
(2000)\end{array}$ & $\begin{array}{l}\text { Hu et al } \\
(2005)\end{array}$ & $\begin{array}{c}\text { This paper } \\
\text { (2007) }\end{array}$ \\
\hline The 3rd stage & Himalayan & & $\begin{array}{l}\text { Yanshanian- } \\
\text { Himalayan }\end{array}$ & $\begin{array}{l}\text { Yanshanian- } \\
\text { Himalayan }\end{array}$ & $\begin{array}{c}\text { Yanshanian- } \\
\text { Himalayan }\end{array}$ & $(\mathrm{K}-\mathrm{Q})$ \\
\hline The 2nd stage & Late Hercynian & $\begin{array}{l}\text { Cretaceous } \\
\text {-Paleogene }\end{array}$ & Late Hercynian & $\begin{array}{l}\text { Late Hercynian- } \\
\text { Indo Chinese }\end{array}$ & Late Hercynian & (C-J) \\
\hline The 1st stage & Late Caledonian & Late Silurian & Late Caledonian & Late Caledonian & Late Caledonian & (S-D) \\
\hline
\end{tabular}



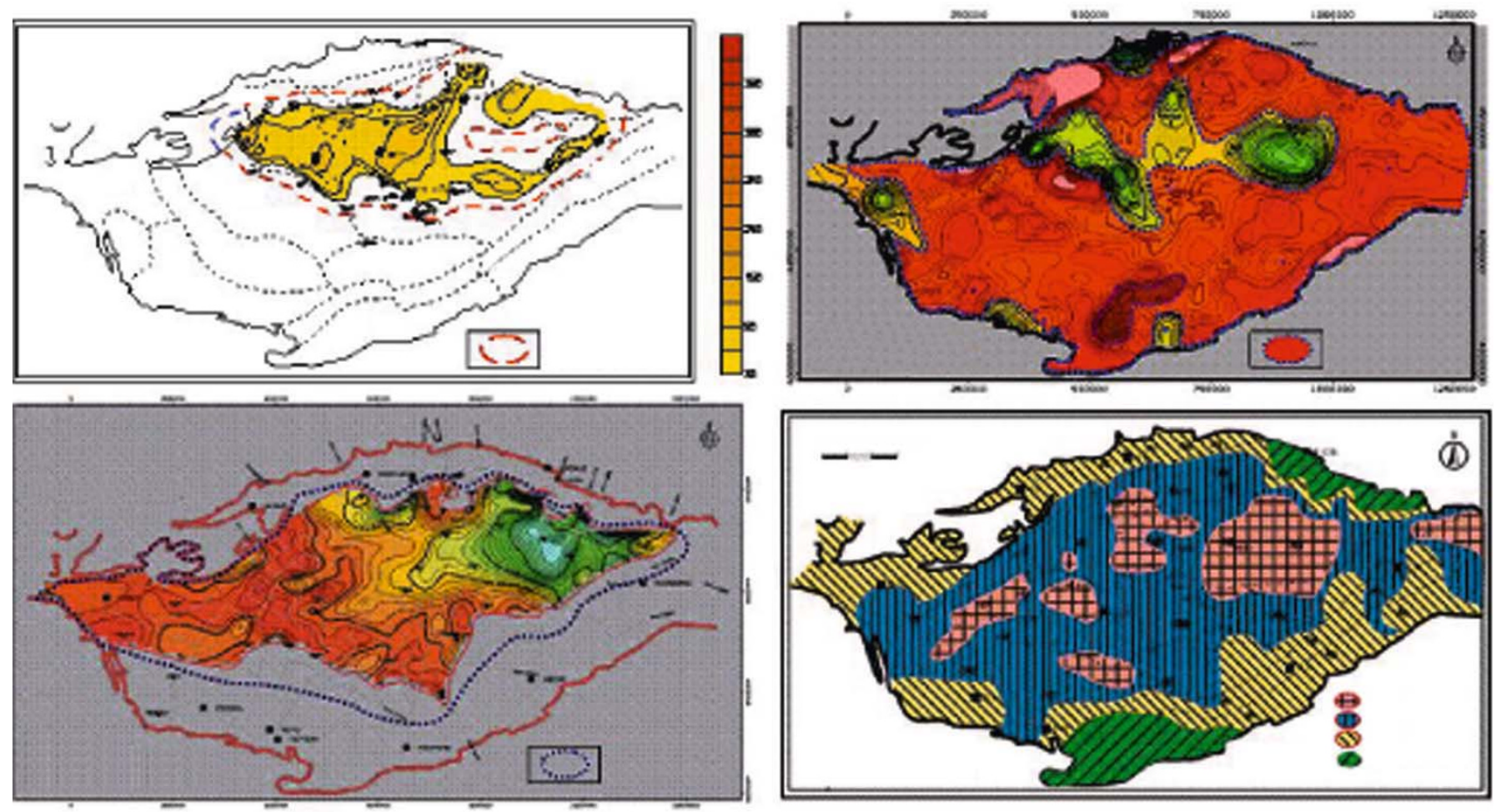

Fig. 1 Distribution map of main controlling factors in the first stage of hydrocarbon accumulation in the Silurian of the Tarim basin

the favorable accumulation area during each of the three oil filling stages of the Silurian by combining controlling factors, the favorable exploration regions following tectonic adjustment and reconstruction of later oil filling stage and the most favorable exploration region by recombination of the favorable exploration fairway in three oil filling stages. The prediction results show that the most favorable exploration region is located in the northeast part of the Manjiaer Sag near the Kongquehe slope and the relatively favorable exploration region in the east part of the Tazhong low uplift, the northwest part of the Awati Sag, the west part of the Luntai uplift, the northwest part of the Kongquehe slope and the Yingjisu depression. As the presently discovered hydrocarbon accumulations are mainly in the favorable exploration region of a particular oil filling stage, the prediction results of the overlapped favorable exploration regions for two or three

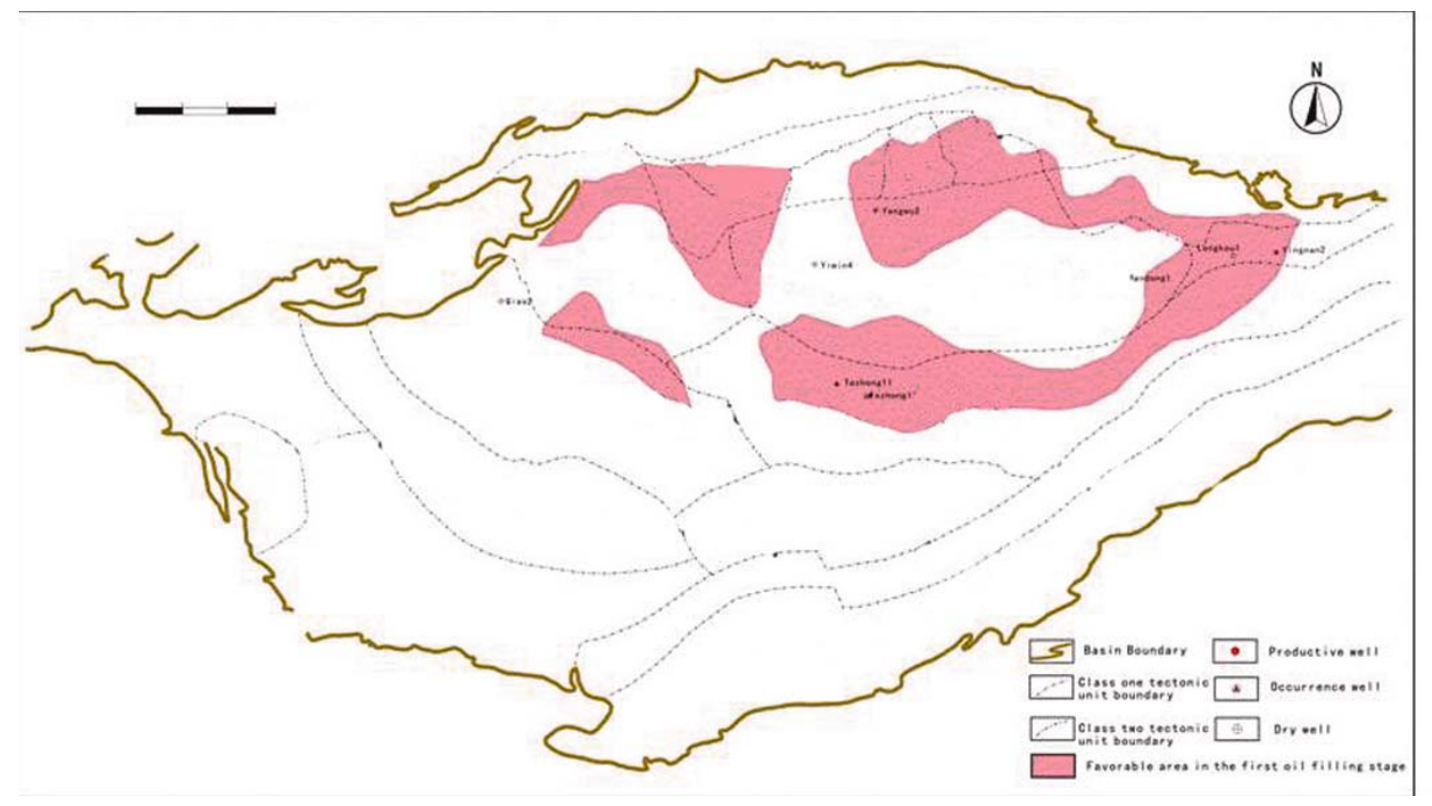

Fig. 2 Predicted favorable areas for the Silurian in Tarim basin based on combination of the main controlling factors in the first oil filling stage 


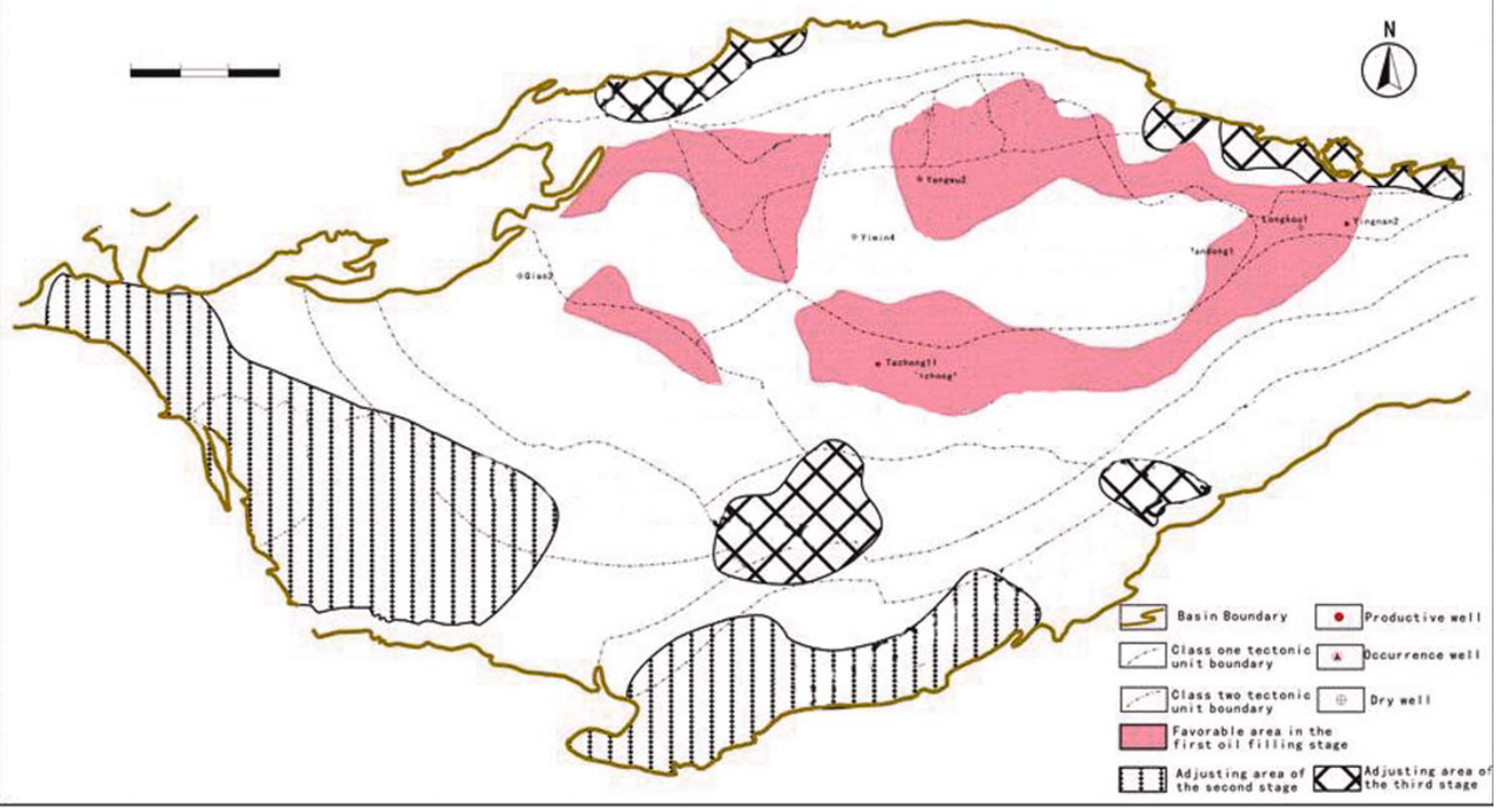

Fig. 3 Structural evolution and adjusting range of favorable area for hydrocarbon accumulations in the first oil filling stage for the Silurian in Tarim basin

oil filling stages will be new favorable areas for further exploration of the Silurian in the Tarim basin.

\subsection{Unanswered Questions}

The prediction results from the "multi-factors combination and processes superimposition" model is just the favorable areas for hydrocarbon formation and enrichment, not the favorable exploration target or even the favorable trap. Whether hydrocarbon got accumulated in the favorable area depends on the development of traps, efficient reservoirs, migration pathways and driving forces. After predicting the favorable exploration region, favorable exploration target can be predicted by considering the above controlling factors.

The prediction result presented in this paper is just a preliminary attempt to predict the favorable accumulation area and exploration region. Whether the result is correct or not does not depend on the predicting model or method, rather on the restoration result of the four key controlling factors.
There are still a lot questions to be resolved in exploration of complex superimposed basins, including the prediction of source rock, shifting of paleo-uplifts, the thickness of eroded sediments in the geological history and so on. It is believed that with the solution of above problems, the model of "multifactors combination and processes superimposition" will play a more and more important role in petroleum exploration.

\section{Acknowledgements}

This work is jointly supported by the National Basic Research Program of China (G1999043310, 2006CB202308).

\section{References}

Chen D X, Pang X Q, Li P L et al. Hydrocarbon accumulation in lacustrine turbidite in the rift basin, Bohai Bay. Petroleum Science. 2006. 3(1): 12-26

Chen Q L and Jiang S J. Reservoir forming stages in Silurian of Central Tarim Basin - A case study of Tazhong wells. West China Petroleum

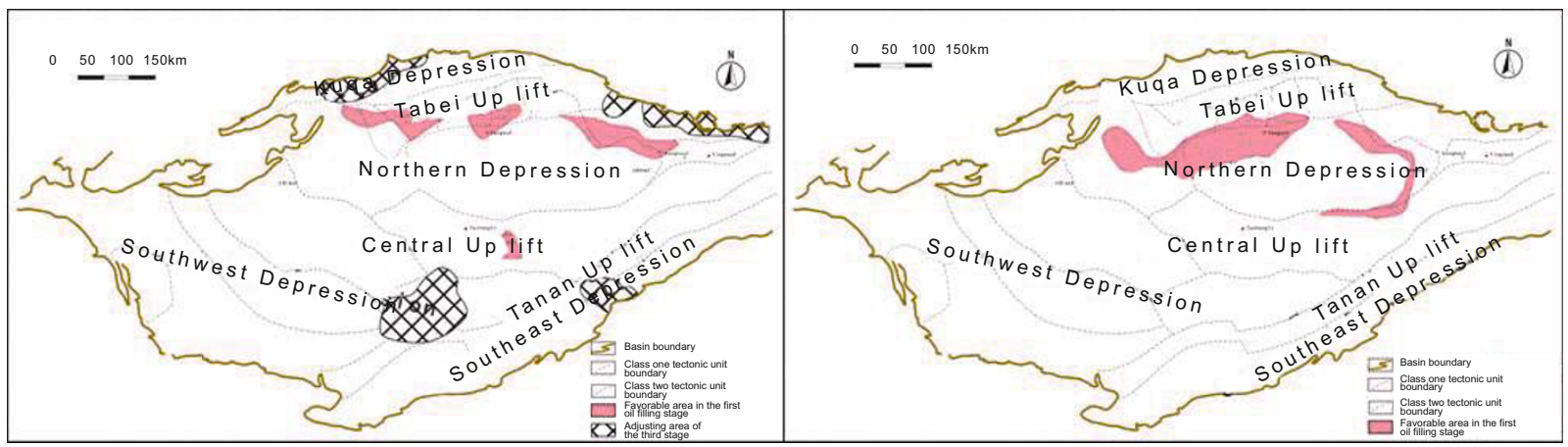

Fig. 4 Structural evolution and adjusting range of favorable area for hydrocarbon accumulations in the second and third oil filling stage of the Silurian in Tarim basin 


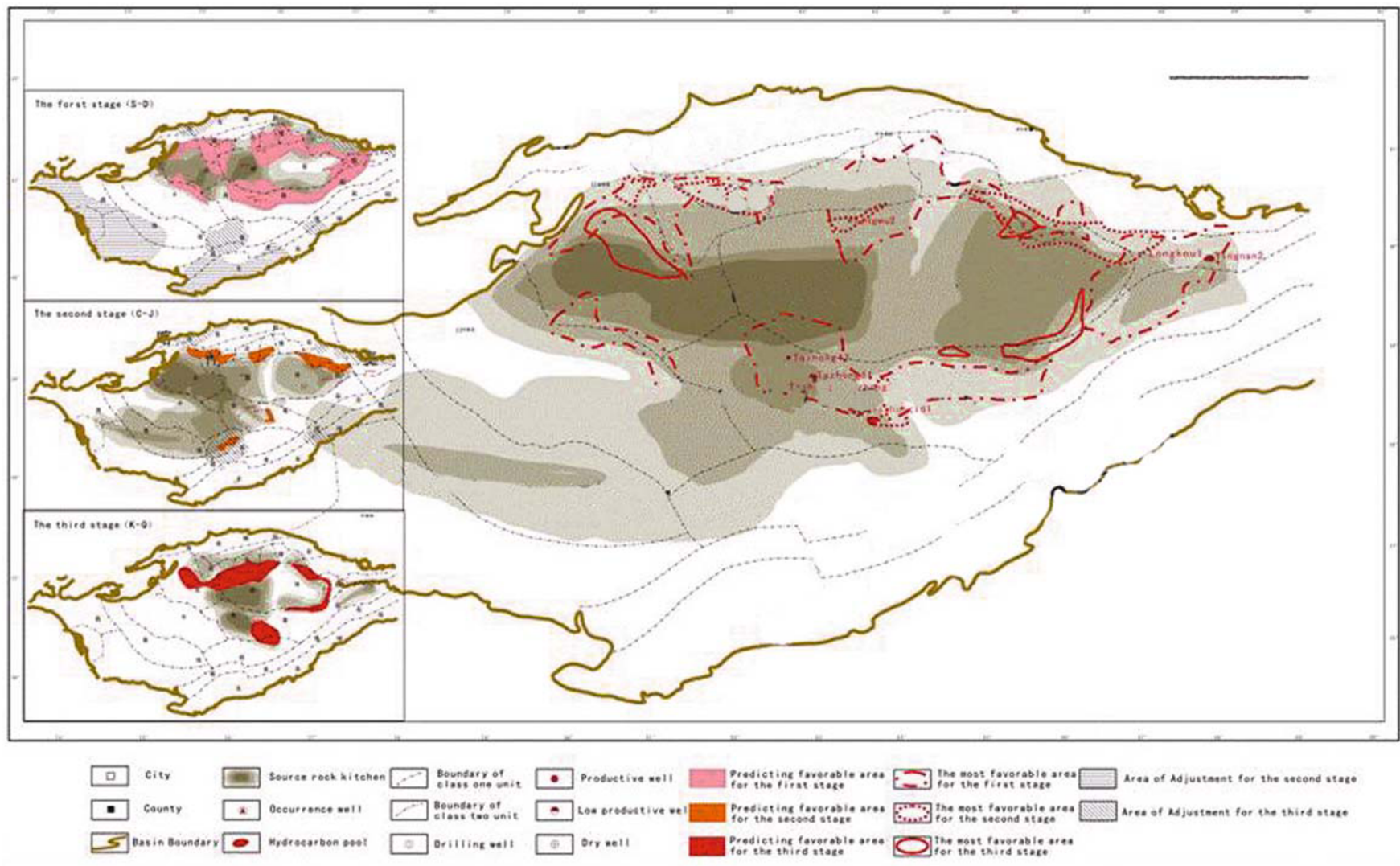

Fig. 5 Integrated assessment map showing favorable Silurian exploration regions in Tarim basin

Geoscience. 2005. 1(1): 62-66 (in Chinese)

He D F, Jia C Z, Zhou X Y, et al. Control principles of structures and tectonics over hydrocarbon accumulation and distribution in multistage superimposed basins. Acta Petrolei Sinica. 2005. 26(3): 1-9 (in Chinese)

Hu J F, Lv X X, Zhao F Y, et al. Controlling factors on petroleum accumulation in Silurian reservoir in Tazhong Uplift of Tarim Basin. Acta Sedimentologica Sinica. 2005. 23(4): 734-740 (in Chinese)

Jiang Z X, Chen D X, Pang X Q, et al. Control of formation of lithological reservoirs by surrounding mudstone. Petroleum Science. 2006. 3(2): 1-6

Jin X H, Yan X B, Zhang S N, et al. Discussion on oil reservoir forming conditions and exploration targets of the Silurian in Tarim Basin. Journal of Xi' an Shiyou University (Natural Science Edition). 2006. 21(2): 1-5 (in Chinese)

Jin Z J and Wang Q C. New advancement in research of China's typical superimposed basins and reservoiring - taking Tarim basin as an example. Science in China (Series D). 2004. 34(S1): 1-12 (in Chinese)

Jin Z J. New advancement in research of China's typical superimposed basins and reservoiring (Part I): classification and research methods of superimposed basins. Oil and Gas Geology. 2005. 26(5): 553-563 (in Chinese)

Li Y P, Wang Y, Sun Y S, et al. Two accumulation stages of the Silurian hydrocarbon reservoirs in central area of the Tarim basin: Discussion on oil reservoir forming conditions and exploration targets of the Silurian in Tarim Basin. Scientia Geologica Sinica. 2002. 37(S1): 45-50 (in Chinese)

Liu L F, Zhao J Z, Zhang S C, et al. Hydrocarbon filling ages and evolution of the Silurian asphalt sandstones in Tarim Basin. Acta Sedimentologica Sinica. 2000. 18(3): 475-480 (in Chinese)

Liu L F, Chen Y Z, Chen L X, et al. Mechanism of Silurian hydrocarbon pool formation in the Tarim Basin. Petroleum Science. 2007. 4(4):
$1-16$

Lu X X, Fan Q H, Zhao F Y, et al. The Silurian play in the Tazhong Uplift, Tarim Basin, northwestern China. Marine and Petroleum Geology. 2007. 24: 189-198

Lu X X and Hu S Y. Hydrocarbon distribution and formation in Tarim basin. Beijing: Petroleum Industrial Press. 1998. 1-87 (in Chinese)

$\mathrm{Lu} \mathrm{X} \mathrm{X,} \mathrm{Jin} \mathrm{Z} \mathrm{J,} \mathrm{Pi} \mathrm{X} \mathrm{J,} \mathrm{et} \mathrm{al.} \mathrm{Hydrocarbon} \mathrm{accumulation} \mathrm{and} \mathrm{distribution}$ of lower Paleozoic carbonate rock in Tarim basin. Science in China (Series D). 1999. 29(4): 358-362 (in Chinese)

Lu X X, Zhao F Y, Yang H J, et al. Multi-source and multi-stage hydrocarbon accumulation and exploration strategy of the Silurian reservoir in Tazhong uplift. Journal of Xi' an Shiyou University (Natural Science Edition). 2005. 20(3): 1-6 (in Chinese)

Pang X Q, Gao J B, Meng Q Y, et al. The model of multi-factors recombination and processes superimposition and its application in superimposed basin - taking researches on Ordovician of Tarim basin as an example. Acta Petrolei Sinica, 2008 (in Chinese) (in Press)

Pang X Q, Gao J B, Meng Q Y, et al. A discussion on the relationship between tectonization and hydrocarbon accumulation and dissipation in the platform-basin transitional area of Tarim basin. Oil and Gas Geology. 2006. 27(5): 594-604 (in Chinese)

Pang X Q, Luo X R, Jiang Z X, et al. Advancements and problems on hydrocarbon accumulation research of complicated superimposed basins in western China. Advances in Earth Science. 2007. 22(2): 879-887 (in Chinese)

Pang X Q, Jin Z J, Jiang Z X, et al. Evaluation of hydrocarbon resources of superimposed basin and its significance. Petroleum Exploration and Development. 2002. 29(1): 9-14 (in Chinese)

Song J G and Wu Z Q. Some considerations on the Silurian petroleum exploration in the Tarim Basin - taking Tazhong region as an example. Petroleum Exploration and Development. 2004. 31(5): 
127-130 (in Chinese)

Zhang G Y, Wang H J, Li H H. Main controls on hydrocarbon accumulation and distribution in Craton area of Tarim basin. Chinese Science Bulletin. 2002. 47(S1): 24-30 (in Chinese)

Zhang S C and Huang H P. Geochemistry of Paleozoic marine petroleum from the Tarim Basin, NW China: Part 1. Oil family classification. Organic Geochemistry. 2005. 36: 1204-1214

Zhao W Z, Zhang G Y, Wang H J, et al. Basic features of petroleum geology in the superimposed petroliferous basins of China and their research methodologies. Petroleum Exploration and Development. 2003. 30(2): 1-8 (in Chinese)
Zhou X X. Essentials about hydrocarbon distribution controlled by source and seal. Petroleum Exploration and Development. 1997. 24(6): 4-9 (in Chinese)

Zhou X X. The petroleum reservoir forming characteristics of the composite superimposed basin — an example from Tarim basin[j]. Earth Science Frontiers. 2000. 7(3): 39-48 (in Chinese)

Zhou X Y, Lu X X, Jin Z J, et al. Accumulation of petroleum in the carbonate rocks in the pivot positions of structural activities in Tarim Basin. Journal of Xi' an Shiyou University (Natural Science Edition). 2004. 19(4): 19-26 (in Chinese)

(Edited by Yang Lei) 